\title{
Basic science: (January 2009)
}

1. Andre F, Job B, Dessen P, Tordai A, Michiels $S$, Liedtke C, Richon C, Yan K, Wang BL, Vassal G, Delaloge S, Hortobagyi GN, Symmans WF, Lazar V, Pusztai L. Molecular characterization of breast cancer with high-resolution oligonucleotide comparative genomic hybridization array. Clin Cancer Res 2009; 15: 441-451.

2. Berg AO, Grp EW, Armstrong K, Botkin J, Calonge $N$, Haddow $J$, Hayes $M$, Kaye $C$, Phillips KA, Piper M, Richards CS, Scott JA, Strickland OL, Teutsch S. Recommendations from the EGAPP Working Group: can tumor gene expression profiling improve outcomes in patients with breast cancer? Genet Med 2009; 11: 66-73.

3. Bourguignon LYW, Xia WL, Wong G. Hyaluronan-mediated CD44 interaction with p300 and SIRT1 regulates beta-catenin signaling and NF kappa B-specific transcription activity leading to MDR1 and $\mathrm{Bcl}-\mathrm{x}(\mathrm{L})$ gene expression and chemoresistance in breast tumor cells. $\mathrm{J}$ Biol Chem 2009; 284: 2657-2671.

4. Crane CA, Panner A, Murray JC, Wilson SP, Xu $\mathrm{H}$, Chen L, Simko JP, Waldman FM, Pieper RO, Parsa AT. PI(3) kinase is associated with a mechanism of immunoresistance in breast and prostate cancer. Oncogene 2009; 28: 306-312.

5. de Muga SV, Timpson P, Cubells L, Evans R, Hayes TE, Rentero C, Hegemann A, Reverter M, Leschner J, Pol A, Tebar F, Daly RJ, Enrich C, Grewal T. Annexin A6 inhibits Ras signalling in breast cancer cells. Oncogene 2009; 28: 363-377.

6. Ding SL, Yu JC, Chen ST, Hsu GC, Kuo SJ, Lin $\mathrm{YH}$, Wu PE, Shen CY. Genetic variants of BLM interact with RAD51 to increase breast cancer susceptibility. Carcinogenesis 2009; 30: 43-49.

7. Feres KJ, Ischenko I, Hayman MJ. The RON receptor tyrosine kinase promotes MSPindependent cell spreading and survival in breast epithelial cells. Oncogene 2009; 28: 279-288.

8. Ghayad SE, Vendrell JA, Bieche I, Spyratos F, Dumontet C, Treilleux I, Lidereau R, Cohen PA.

First published online 14/07/09

BCO/850/2009/JW
Identification of TACC1, NOV, and PTTG1 as new candidate genes associated with endocrine therapy resistance in breast cancer. $\mathrm{J} \mathrm{Mol}$ Endocrinol 2009; 42: 87-103.

9. Hu ZB, Liang J, Wang ZW, Tian T, Zhou XY, Chen JP, Miao RF, Wang Y, Wang XR, Shen HB. Common genetic variants in pre-microRNAs were associated with increased risk of breast cancer in Chinese women. Hum Mutat 2009; 30: 79-84.

10. Kok M, Linn SC, Van Laar RK, Jansen M, van den Berg TM, Delahaye L, Glas AM, Peterse JL, Hauptmann M, Foekens JA, Klijn JGM, Wessels LFA, Van't Veer LJ, Berns E. Comparison of gene expression profiles predicting progression in breast cancer patients treated with tamoxifen. Breast Cancer Res Treat 2009; 113: 275-283.

11. Lower EE, Glass E, Blau R, Harman S. HER-2/ neu expression in primary and metastatic breast cancer. Breast Cancer Res Treat 2009; 113: 301-306.

12. Lund MJ, Trivers KF, Porter PL, Coates RJ, Leyland-Jones B, Brawley OW, Flagg EW, O'Regan RM, Gabram SGA, Eley JW. Race and triple negative threats to breast cancer survival: a population-based study in Atlanta, GA. Breast Cancer Res Treat 2009; 113: 357-370.

13. Luo M, Fan HP, Nagy T, Wei HJ, Wang CR, Liu SL, Wicha MS, Guan JL. Mammary epithelialspecific ablation of the focal adhesion kinase suppresses mammary tumorigenesis by affecting mammary cancer stem/progenitor cells. Cancer Res 2009; 69: 466-474.

14. Manie E, Vincent-Salomon A, Lehmann-Che J, Pierron G, Turpin E, Warcoin M, Gruel N, Lebigot I, Sastre-Garau X, Lidereau R, Remenieras A, Feunteun J, Delattre O, de The H, StoppaLyonnet D, Stern MH. High frequency of TP53 mutation in BRCA1 and sporadic basal-like carcinomas but not in BRCA1 luminal breast tumors. Cancer Res 2009; 69: 663-671.

15. Meijer D, Jansen M, Look MP, Ruigrok-Ritstier K, van Staveren IL, Sieuwerts AM, van Agthoven T, 
Foekens JA, Dorssers LCJ, Berns E. TSC22D1 and PSAP predict clinical outcome of tamoxifen treatment in patients with recurrent breast cancer. Breast Cancer Res Treat 2009; 113: 253-260.

16. Millar EK, Anderson LR, McNeil CM, O'Toole SA, Pinese M, Crea P, Morey AL, Biankin AV, Henshall SM, Musgrove EA, Sutherland RL, Butt AJ. BAG-1 predicts patient outcome and tamoxifen responsiveness in ER-positive invasive ductal carcinoma of the breast. $\mathrm{Br} J$ Cancer 2009; 100: 123-133.

17. Mirzoeva OK, Das D, Heiser LM, Bhattacharya S, Siwak D, Gendelman R, Bayani N, Wang NJ, Neve RM, Guan Y, Hu Z, Knight Z, Feiler HS, Gascard P, Parvin B, Spellman PT, Shokat KM, Wyrobek AJ, Bissell MJ, McCormick F, Kuo WL, Mills GB, Gray JW, Korn WM. Basal subtype and MAPK/ERK kinase (MEK)phosphoinositide 3-kinase feedback signaling determine susceptibility of breast cancer cells to MEK inhibition. Cancer Res 2009; 69: 565-572.

18. Mourtada-Maarabouni M, Pickard MR, Hedge VL, Farzaneh F, Williams GT. GAS5, a nonprotein-coding RNA, controls apoptosis and is downregulated in breast cancer. Oncogene 2009; 28: 195-208.

19. Pilones KA, Kawashima N, Yang AM, Babb JS, Formenti SC, Demaria S. Invariant natural killer $T$ cells regulate breast cancer response to radiation and CTLA-4 blockade. Clin Cancer Res 2009; 15: 597-606.

20. Smith AP, Verrecchia A, Faga G, Doni M, Perna D, Martinato F, Guccione E, Amati B. A positive role for Myc in TGF beta-induced snail transcription and epithelial-to-mesenchymal transition. Oncogene 2009; 28: 422-430.

21. Strecker TE, Shen Q, Zhang Y, Hill JL, Li YX, Wang C, Kim HT, Gilmer TM, Sexton KR, Hilsenbeck SG, Osborne CK, Brown PH. Effect of lapatinib on the development of estrogen receptor-negative mammary tumors in mice. J Natl Cancer Inst 2009; 101: 107-113.
22. Tan EY, Yan M, Campo L, Han C, Takano E, Turley H, Candiloro I, Pezzella F, Gatter KC, Millar EKA, O'Toole SA, McNeil CM, Crea P, Segara $D$, Sutherland RL, Harris AL, Fox SB. The key hypoxia regulated gene CAIX is upregulated in basal-like breast tumours and is associated with resistance to chemotherapy. Br J Cancer 2009; 100: 405-411.

23. Tchatchou $S$, Jung $A$, Hemminki $K$, Sutter $C$, Wappenschmidt B, Bugert P, Weber BHF, Niederacher D, Arnold N, Varon-Mateeva R, Ditsch N, Meindl A, Schmutzler RK, Bartram CR, Burwinkel B. A variant affecting a putative miRNA target site in estrogen receptor (ESR) 1 is associated with breast cancer risk in premenopausal women. Carcinogenesis 2009; 30: 59-64.

24. Thomassen M, Tan QH, Kruse TA. Gene expression meta-analysis identifies chromosomal regions and candidate genes involved in breast cancer metastasis. Breast Cancer Res Treat 2009; 113: 239-249.

25. Wang SE, Xiang B, Zent R, Quaranta V, Pozzi A, Arteaga CL. Transforming growth factor beta induces clustering of HER2 and integrins by activating Src-focal adhesion kinase and receptor association to the cytoskeleton. Cancer Res 2009; 69: 475-482.

26. Wu F, Ivanov I, Xu R, Safe S. Role of SP transcription factors in hormone-dependent modulation of genes in MCF-7 breast cancer cells: microarray and RNA interference studies. $\mathrm{J}$ Mol Endocrinol 2009; 42: 19-33.

27. Zhao XS, Lu L, Pokhriyal N, Ma H, Duan L, Lin $\mathrm{S}$, Jafari N, Band H, Band V. Overexpression of RhoA induces preneoplastic transformation of primary mammary epithelial cells. Cancer Res 2009; 69: 483-491.

Prepared by

$R$ Sutherland

Cancer Research Program

Garvan Institute of Medical Research Darlinghurst, NSW, Australia 